Palearctic and Indian mammals 1758 to 1946. British Museum: 1-810. London. Folk G. E., Jr., 1966: Introduction to environmental physiology. Lea Febiger: 1-307. Philadelphia. G e rma n A. L., 1961: The degree of resistance to water defficiency in some mouse-like rodents of the steppe zone [in Russian with English summary]. Zool. Ž., 40, 6: 914-921. Petz s c h H., 1952: Der Hamster. Akad. Verl. Ges. Geest und Portig K.-G.; 1-54. Leipzig. S c h m i d t-N i e l s e n K., 1964: Desert animals, physiological problems of heat and water. Clarendon Press: 1-277.

Department of Animal Ecology, Jagiellonian University, 30-060 Kraków, Krupnicza 50, Poland. Received, December 4, 1972.

I. Jack STOUT \& Daniel E. SONENSHINE

\title{
A CONVENIENT BAIT FOR SMALL MAMMAL LIVETRAPPING STUDIES
}

\author{
PROSTA PRZYNĘTA DO ODEOWU DROBNYCH SSAKOW
}

Verts (1961) and Smith et al. (1969) provided information on baiting snap traps. We found these methods were not suitable for livetrapping where our criteria of an acceptable bait included the following: does not interfere with the treadle operation; does maximize likelihood of animal walking on treadle; can serve as source of energy when animals remain in traps overnight; is easily made; and is efficient to use in the field regardless of season.

For nearly 10 years we have used a bait that meets these criteria. The baits look like large "candy kisses «. Approximately $10 \times 10 \mathrm{~cm}$ squares of wax paper are cut from a roll using a heavy knife or saw. A teaspoon of peanut butter is applied to the center of a square of wax paper. Other components dictated by study objectives may be added: mixed grains, raisins, bacon grease, cats, or rabbit pellets. The opposite corners of the wax paper are pulled together and twisted to contain the bait. Quantities of baits may be stored frozen until needed.

The twisted end of the bait is easily held in place between the top of the rear door and the roof of a Sherman type trap.

We have used the baits in a variety of habitats in Virginia and Washington in all seasons. Small mammals including Microtus pennsylvanicus, M. montanus, M. longicaudus, Peromyscus leucopus, P. maniculatus, Reithrodontomys humulis, Tamias striatus, Eutamias amoenus, Glaucomys volans and various Sorex sp. utilize the baits, particularly in winter.

Support for this work was provided by contract DA-49-193-MD-2439, with the U. S. Army Research and Development Command, Washington, D. C. and U. S. Public Health Service Grant 5T01-ES000-89-ESTC to Vincent Schultz.

\section{REFERENCES}

S mith M. H., Chew R. M. \& G entry G. B., 1969: New technique for baiting snap traps. Acta theriol., 14, 19: 271. V e r t s B. J., 1961: A convenient method of carrying and dispensing baits. J. Mammal., 42, 2: 283.

Department of Biological Sciences, Florida Technological University, Box 25000, Orlando, Florida 32816 (I.J.S.) and Department of Biology, Old Dominion University, Norfolk, Virginia 23508 (D.E.S.). Accepted, December 22, 1972. 